\title{
Revision of the Stereochemistry of Elisabethatriene, a Putative Biosynthetic Intermediate of Pseudopterosins
}

\author{
Masayuki Nasuda, Miho Ohmori, Kiyoshi Ohyama, and Yoshinori Fujimoto* \\ Department of Chemistry and Materials Science, Tokyo Institute of Technology; Meguro-ku, Tokyo 152-8551, Japan. \\ Received February 17, 2012; accepted March 5, 2012
}

In the past, we have questioned the accuracy of the stereochemistry of elisabethatriene, a putative biosynthetic intermediate of pseudopterosins, in light of the configuration of elisabethatrienol isolated from Pseudopterogorgia elisabethae, which was represented as $1 S, 4 R, 9 S, 11 S$. We have reinvestigated the stereochemistry of elisabethatriene. Elisabethatriene with the reported $1 S, 4 R, 9 R, 11 S$ configuration was synthesized starting from (-)-isopulegol in its enantiomeric form. The ${ }^{1} \mathrm{H}$ - and ${ }^{13} \mathrm{C}-\mathrm{NMR}$ data of the synthesized compound differed from those reported for elisabethatriene. In addition to the fact that elisabethatriene is converted into pseudopterosins, this finding has allowed us to propose that elisabethatriene should have the $1 S, 4 R, 9 S, 11 S$ stereochemistry, which is identical to that of elisabethatrienol.

Key words elisabethatriene; elisabethatrienol; pseudopterosin; Pseudopterogorgia elisabethae

Pseudopterosins are glycosylated tricyclic diterpenes isolated from marine octocoral, Pseudopterogorgia elisabethae, and more than thirty compounds in this class have been reported ${ }^{1)}$ since the first isolation of pseudopterosins A-D. ${ }^{2)}$ Our group reported the isolation and characterization of pseudopterosins $\mathrm{P}-\mathrm{V}$ as well as related non-glycosylated diterpenes, including elisabethatrienol (1) and seco-pseudopterosin K from $P$. elisabethae collected in San Andres and Providencia Islands in the Colombian Caribbean. ${ }^{3,4)}$ It has been reported that pseudopterosin A displays potent anti-inflammatory activity ${ }^{2)}$ by inhibiting both phospholipase A2 and 5-lipoxygenase. ${ }^{5)}$

The biosynthesis of pseudopterosins was studied by Kerr's group. $\left.{ }^{6}\right)$ These researchers reported the formation of a bicyclic compound named elisabethatriene (2a) upon incubation of geranylgeranyl diphosphate (GGPP) with a cell free preparation of $P$. elisabethae. Elisabethatriene has four stereogenic centers that were represented as $1 S, 4 R, 9 R, 11 S$ (the pseudopterosin numbering system is applied). ${ }^{7}$ These researchers also reported that incubation of elisabethatriene with the same preparation yielded erogorgiaene (3), ${ }^{8)}$ which was further converted to pseudopterosins ${ }^{8)}$ (Chart 1). Elisabethatrienol (1), a hydroxylated analogue of elisabethatriene, isolated by our group was determined to have the $1 S, 4 R, 9 S, 11 S$ configuration on the basis of detailed nuclear Overhauser effect (NOE) experiments. ${ }^{4)}$ It is of note that compounds elisabethatrienol and elisabethatriene have the opposite configuration at C-9, even though the stereogenic center disappears in the following intermediate 3. This finding raised the possibility that elisabethatriene could have the $1 S, 4 R, 9 S, 11 S$ configuration (namely compound 4) rather than the reported $1 S, 4 R, 9 R, 11 S$ configuration, since it would be reasonable to assume that the identical stereochemical mechanism is operating in the cyclization of GGPP leading to the two compounds. $\left.{ }^{4}\right)$

In this article, we report the results from the reinvestigation of the stereochemistry that was reported for elisabethatriene. This study establishes that the stereochemistry of elisabethatriene was incorrect and the correct stereochemistry is $1 S, 4 R, 9 S, 11 S$.<smiles>CC=CC(C=C(C)C)(C=C(C)C)CC(C)=CCCC(C)=CC</smiles>

GGPP

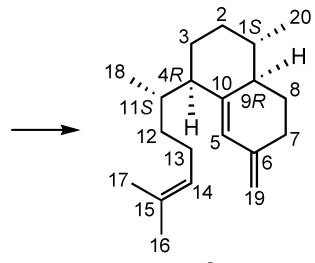

$2 a$

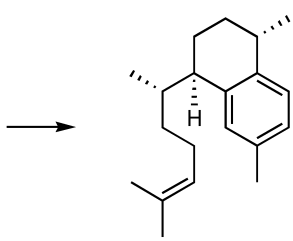

3

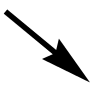

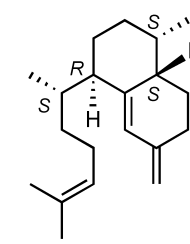

4

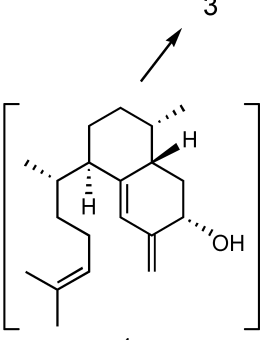

pseudopterosin A

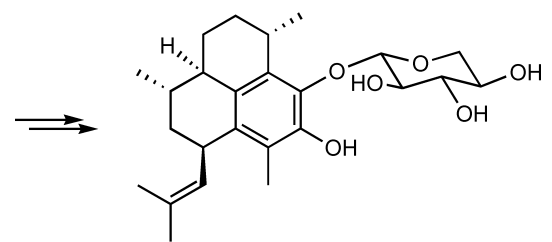$$
\text { (1) }
$$

12

Chart 1. Biosynthesis of Pseudopterosins

The present study indicated that the structure of the bicyclic intermediate arising from GGPP is compound $\mathbf{4}$ rather than compound 2a.

The authors declare no conflict of interest. 


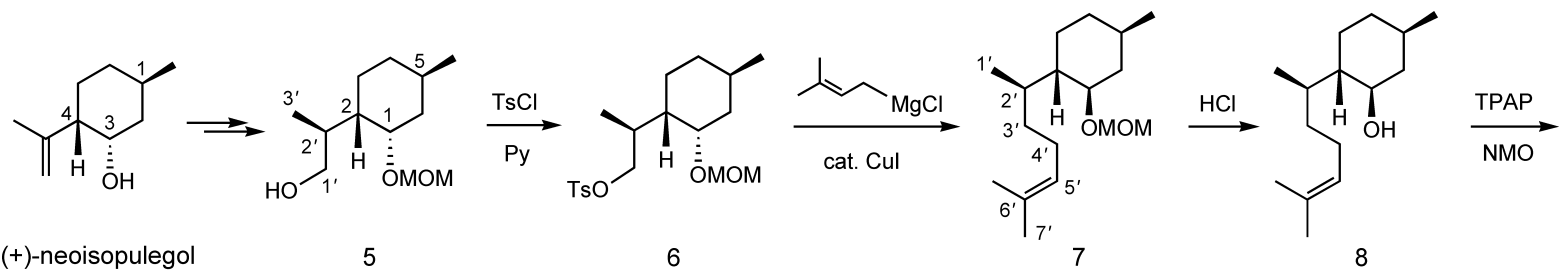

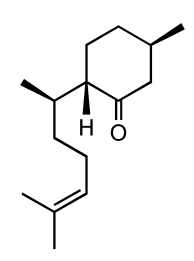

9

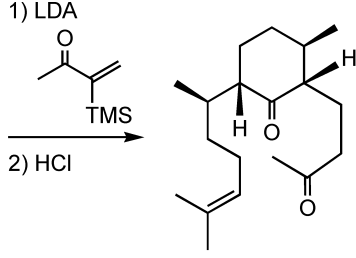

10

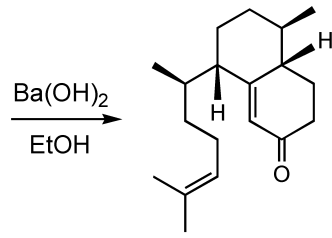

11

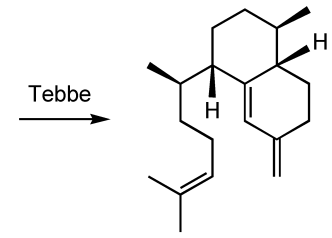

$2 b$

Chart 2. Synthesis of Compound $\mathbf{2 b}$

\section{Results and Discussion}

We decided to synthesize the structure proposed for elisabethatriene and compare the NMR data with those reported for elisabethatriene to examine whether the reported structure is correct. The outline of our retro-synthesis for the target compound $\mathbf{2 b}$ (the antipode of $\mathbf{2 a}$, vide infra) is described below. The methylene moiety found in compound $\mathbf{2 b}$ could be introduced easily onto the corresponding enone (see compound 11 in Chart 2). Thus, the enone having the desired configuration at the $\mathrm{C}-1, \mathrm{C}-4$ and $\mathrm{C}-11$ positions becomes a requisite precursor. Such an enone could be readily obtained by the Robinson annulation strategy from an appropriate trans-2-alkyl-5-methylcyclohexanone, such as compound 9. ${ }^{9-11)}$ Manipulation of the 6-methylhept-5-en-2-yl moiety at the $\mathrm{C}-2$ position of an appropriate 5-methylcyclohexanone ring at an early stage would simplify the synthesis. The analysis led to a $p$-menthanediol derivative such as 2-(1-hydroxyprop2-yl)-5-methylcyclohexan-1-ol methoxymethyl (MOM) ether 5 (cyclohexane numbering system is applied) as a candidate of the starting material. The $\left(1 S, 2 S, 5 R, 2^{\prime} S\right)$-MOM ether $\mathbf{5}$ is a known compound that can be prepared from commercially available $(-)-(1 R, 3 R, 4 S)$-isopulegol. ${ }^{12,13)}$ The use of $(-)$-isopulegol would lead to the antipode of the target molecule $\mathbf{2 b}$ $(1 S, 4 R, 9 R, 11 S$ configuration). This is acceptable in the present study, because we are concerned with the relative stereochemistry of $\mathbf{2 a}$. Thus, compound $\mathbf{2 b}$ was chosen as our synthetic target.

A sample of (-)-isopulegol purchased from Tokyo Kasei Co., Japan was an approximately 5:1 mixture of $(-)-(1 R, 3 R, 4 S)$-isopulegol and (+)-(1R,3S,4S)-neoisopulegol (the menthane numbering system is applied). The mixture was converted to neoisopulegol via oxidation and reduction according to a previously published protocol. ${ }^{14)}$ The sample of neoisopulegol was determined to be $66 \%$ enantiomeric excess (ee) by the application of the Mosher's ester method with the $(+)-(1 R, 3 S, 4 S)$-form being predominant $\left([\alpha]_{D}^{25}+20.2(c=1.63\right.$, $\left.\mathrm{CHCl}_{3}\right)$, lit. ${ }^{13)}-22.2$ for $(-)-(1 S, 3 R, 4 R)$-form). For the sake of simplicity, we hereafter describe compounds of $66 \%$ ee by prefixing the $R / S$ stereochemical designation to the compound names. The sample of $\left(1 R, 3 S, 4 S, 2^{\prime} S\right)$-MOM ether 5 obtained by hydroboration-oxidation of the $(1 R, 3 S, 4 S)$-neoisopulegol as described previously ${ }^{12)}$ was used in the present synthesis.
The tosylate derivative $\mathbf{6}$ obtained from $\mathbf{5}$ was subjected to copper catalyzed Grignard reaction using 3-methylbut-2-enyl magnesium chloride to yield coupling product 7 in moderate yield. A small amount (approximately 10\%) of 2-isopropyl5-methylcyclohexan-1-ol MOM ether was also obtained. The acidic treatment of compound 7 under reflux conditions in tetrahydrofuran (THF) yielded a deprotected product, which was purified by silica gel chromatography to remove the minor product, 2-isopropyl-5-methylcyclohexan-1-ol, and afforded cyclohexanol $\mathbf{8}$ in $39 \%$ yield from $\mathbf{6}$. TPAP oxidation of 8 gave cyclohexanone $\mathbf{9}$. The reaction of an enolate generated from 9 by lithium diisopropylamide (LDA) treatment with 3 -trimethylsilylbut-3-en-2-one followed by exposure of the reaction mixture to acidic conditions yielded the 3-oxobutylcyclohexanone $\mathbf{1 0}$ in $49 \%$ yield. $^{9-11)}$ Robinson annulation of $\mathbf{1 0}$ under the condition of $\mathrm{Ba}(\mathrm{OH})_{2}$ in $\mathrm{EtOH}$ afforded enone $\mathbf{1 1}$ in $39 \%$ yield. Syn orientation of H-4 and H-9 in $\mathbf{1 1}$ was expected based on results in the literature, ${ }^{9-11)}$ and this expectation was confirmed by NOE experiments, in which the NOE correlation was observed between the two hydrogens $[\mathrm{H}-4(\delta$ 1.62) and H-9 $\left(\delta\right.$ 1.27), in benzene- $\left.d_{6}\right]$. Tebbe olefination of enone 11 completed the synthesis of $\mathbf{2 b}$.

The ${ }^{1} \mathrm{H}$ and ${ }^{13} \mathrm{C}$ signals of $\mathbf{2 b}$ were assigned by $2 \mathrm{D}$-NMR experiments, including $\mathrm{H}-\mathrm{H}$ correlation spectroscopy (COSY), heteronuclear multiple quantum coherence (HMQC) and heteronuclear multiple bond connectivity (HMBC) spectra (Table 1 , in benzene- $d_{6}$ ). Extensive decoupling experiments allowed us to determine the coupling constants of $J_{\mathrm{H}-9, \mathrm{H}-8 \mathrm{ax}}=7.5 \mathrm{~Hz}$, $J_{\mathrm{H}-9, \mathrm{H}-8 \mathrm{eq}}=5.7 \mathrm{~Hz}, J_{\mathrm{H}-9, \mathrm{H}-1}=10.2 \mathrm{~Hz}$. The large coupling constants of $J_{\mathrm{H}-9, \mathrm{H}-8 \mathrm{ax}}$ and $J_{\mathrm{H}-9, \mathrm{H}-1}$ implied that these three hydrogens exhibit nearly axial orientation. Furthermore, irradiation of H-9 $(\delta 1.50)$ caused NOE enhancement to the signals of $\mathrm{H}-4(\delta 1.74)$, one of the methylene protons at $\mathrm{C}-2(\delta 1.05)$ and $\mathrm{H}_{3}-20(\delta 0.84)$. These findings provided evidence for the $s y n$ relationships of $\mathrm{H}-4$ and $\mathrm{H}-9$. The most stable conformation deduced from MM2 calculation is depicted in Fig. 1. Thus, the synthesized material $\mathbf{2 b}$ has the $1 R, 4 S, 9 S, 11 R$ configuration, and its antipode 2 a should have the $1 S, 4 R, 9 R, 11 S$ configuration.

Comparison of the ${ }^{13} \mathrm{C}-\mathrm{NMR}$ data (recorded in benzene- $d_{6}$, since elisabethatriene was analyzed in the same solvent) of the stereochemically defined $\mathbf{2} \mathbf{b}$ with those of elisabethatriene 
Table 1. ${ }^{1} \mathrm{H}-(500 \mathrm{MHz})$ and ${ }^{13} \mathrm{C}-(125 \mathrm{MHz})$ NMR Data (in Benzene- $\left.d_{6}\right)$ for Compounds $\mathbf{2 b}$ and $\mathbf{2 a}$

\begin{tabular}{|c|c|c|c|c|c|}
\hline \multirow{2}{*}{ Position } & \multicolumn{3}{|c|}{$2 \mathbf{b}$} & \multicolumn{2}{|c|}{$2 a^{a)}$} \\
\hline & $\delta_{\mathrm{H}}$ (mult., $J \mathrm{~Hz}$ ) & $\delta_{\mathrm{C}}$ & $\mathrm{HMBC}(\mathrm{H} \rightarrow \mathrm{C})$ & $\delta_{\mathrm{H}}$ (mult., $J \mathrm{~Hz}$ ) & $\delta_{\mathrm{C}}$ \\
\hline 1 & $1.13\left(\mathrm{~m}^{b)}\right)$ & 39.5 & & $1.70(\mathrm{~m})$ & 31.9 \\
\hline \multirow[t]{2}{*}{2} & $1.05(\mathrm{~m})$ & 35.9 & & $1.20(\mathrm{~m})$ & 23.2 \\
\hline & $1.65(\mathrm{~m})$ & & & $1.60(\mathrm{~m})$ & \\
\hline \multirow[t]{2}{*}{3} & $1.03(\mathrm{~m})$ & $28.0^{c)}$ & & $1.45(\mathrm{~m})$ & 27.5 \\
\hline & $1.72(\mathrm{~m})$ & & $\mathrm{C}-1$ & $1.58(\mathrm{~m})$ & \\
\hline 4 & $1.74(\mathrm{~m})$ & 49.6 & C-5, C-18 & $2.24(\mathrm{~m})$ & 37.1 \\
\hline 5 & $6.15(\mathrm{~s})$ & 121.7 & & $6.12(\mathrm{~d}, 2)$ & 127.5 \\
\hline 6 & - & 144.6 & & - & 144.0 \\
\hline \multirow[t]{2}{*}{7} & $2.18(\mathrm{~m})$ & 29.4 & & $2.15(\mathrm{~m})$ & 29.8 \\
\hline & $2.32(\mathrm{~m})$ & & & $2.34(\mathrm{~m})$ & \\
\hline \multirow[t]{2}{*}{8} & $1.40\left(\mathrm{~m}^{b)}\right)$ & $27.9^{c)}$ & C-9 & $1.02(\mathrm{~m})$ & 35.2 \\
\hline & $1.89\left(\mathrm{~m}^{b)}\right)$ & & & $1.59(\mathrm{~m})$ & \\
\hline 9 & $1.50\left(\mathrm{~m}^{b)}\right)$ & 45.3 & & $1.80(\mathrm{~m})$ & 49.9 \\
\hline 10 & - & 146.4 & & - & 143.9 \\
\hline 11 & $1.98(\mathrm{~m})$ & 31.9 & & $1.77(\mathrm{~m})$ & 35.5 \\
\hline \multirow[t]{2}{*}{12} & $1.05(\mathrm{~m})$ & 32.8 & & $1.20(\mathrm{~m})$ & 29.6 \\
\hline & $1.65(\mathrm{~m})$ & & C-4 & $1.63(\mathrm{~m})$ & \\
\hline \multirow[t]{2}{*}{13} & $2.07(\mathrm{~m})$ & 26.6 & C-11, C-12, C-14 & $1.96(\mathrm{~m})$ & 25.9 \\
\hline & $2.18(\mathrm{~m})$ & & $\mathrm{C}-14$ & $2.15(\mathrm{~m})$ & \\
\hline 14 & $5.31(\mathrm{brt}, 7.5)$ & 125.4 & & $5.19(\mathrm{~m})$ & 125.6 \\
\hline 15 & - & 131.2 & & - & 130.9 \\
\hline 16 & $1.71(\mathrm{~s})$ & 25.9 & C-14, C-15 & $1.63(\mathrm{~d}, 4.5)$ & 25.9 \\
\hline 17 & $1.61(\mathrm{~s})$ & 17.6 & C-14, C-15 & $1.57(\mathrm{~s})$ & 17.7 \\
\hline 18 & $0.99(\mathrm{~d}, 6.8)$ & 18.9 & C-4, C-11, C-12 & $0.85(\mathrm{~d}, 7.5)$ & 15.1 \\
\hline \multirow[t]{2}{*}{19} & $4.85(\mathrm{~s})$ & 108.9 & $\mathrm{C}-5, \mathrm{C}-7$ & $4.76(\mathrm{dd}, 1.5,1.0)$ & 109.0 \\
\hline & $4.96(\mathrm{~s})$ & & C-5, C-7 & $4.85(\mathrm{~s})$ & \\
\hline 20 & $0.84(\mathrm{~d}, 6.4)$ & 20.4 & C-1, C-2, C-9 & $0.89(\mathrm{~d}, 6.5)$ & 17.6 \\
\hline
\end{tabular}

a) Adopted from ref. 7. b) For the accurate coupling constants revealed by decoupling experiments, see text. $c$ ) Interchangeable.

reported by Coleman and $\mathrm{Kerr}^{7)}$ indicated that the two compounds are apparently different from each other (even though some of their ${ }^{13} \mathrm{C}$ assignments were interchanged). In particular, the ${ }^{13} \mathrm{C}$ shifts of $\mathrm{C}-1, \mathrm{C}-4, \mathrm{C}-5$ and $\mathrm{C}-8$ deviated by more than five ppm (Table 1). Therefore, the stereochemical assignment of elisabethatriene was incorrect and needs to be revised. Elisabethatriene was reported to be metabolized into pseudopterosins. This result implies that the configurations at $\mathrm{C}-1, \mathrm{C}-4$ and $\mathrm{C}-11$ positions of elisabethatriene are identical with those of pseudopterosins (i.e., $1 S, 4 R, 11 S$ ). Thus, we conclude that elisabethatriene has the $1 S, 4 R, 9 S, 11 S$ configuration and is represented as 4 .

The reason for the erroneous stereochemical assignment was not apparent but may be due to the quality and interpretation of the NOE data. The assignments failed to describe the NOE correlation between H-9 and H-4 that should have been observed for the assigned structure to be correct.

In conclusion, the present study reinvestigated the stereochemistry of elisabethatriene, and the previously reported stereochemistry for elisabethatriene was revised to be $1 S, 4 R, 9 S, 11 S$. This reassignment confirmed that the identical stereochemical mechanism is operating in the enzymic formation of elisabethatriene and elisabethatrienol. A sesquiterpene analogue of elisabethatriene, nephthene (12), isolated from an Okinawan soft coral of Nephthea sp., ${ }^{15}$ could be formed by an enzyme that cyclizes farnesyl diphosphate in the same stereochemical mode as $\mathbf{1}$ and $\mathbf{4}$. The present study indicated that the biosynthesis of pseudopterosins proceeds via compound $\mathbf{4}$,

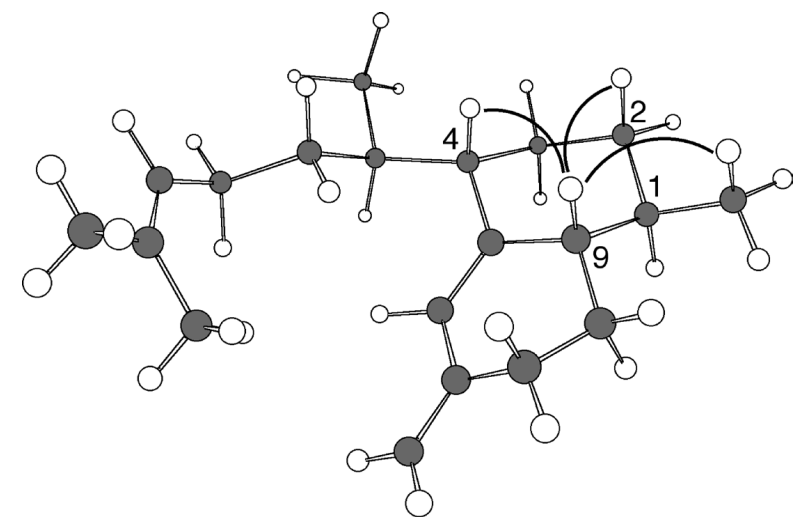

Fig. 1. Pertinent NOE Correlations and Most Stable Conformation for Compound $\mathbf{2 b}$

but not compound $\mathbf{2 a}$, as indicated in Chart 1 . It remains an open question as to whether elisabethatrienol (1) is a biosynthetic intermediate leading to erogorgiaene (3).

\section{Experimental}

General Experimental Procedures Melting point was determined on a Yazawa hot-stage melting point apparatus and are uncorrected. ${ }^{1} \mathrm{H}$ - and ${ }^{13} \mathrm{C}$-NMR spectra were obtained on a JEOL AL-400 $\left(400 \mathrm{MHz}\right.$ for ${ }^{1} \mathrm{H}$ and $100 \mathrm{MHz}$ for $\left.{ }^{13} \mathrm{C}\right)$ spectrometer in $\mathrm{CDCl}_{3}$. ${ }^{1} \mathrm{H}$ chemical shifts are reported relative to tetramethylsilane $(\delta 0.00)$ or benzene- $d_{6}(\delta 7.16)$, while 
${ }^{13} \mathrm{C}$ chemical shifts are reported relative to $\mathrm{CDCl}_{3}(\delta 77.00)$. Compounds $\mathbf{1 1}$ and $\mathbf{2 b}$ were recorded on a Bruker DRX-500 $\left(500 \mathrm{MHz}\right.$ for ${ }^{1} \mathrm{H}$ and $125 \mathrm{MHz}$ for ${ }^{13} \mathrm{C}$ ) spectrometer in $\mathrm{CDCl}_{3}$ and benzene- $d_{6}$. When recorded in benzene- $d_{6},{ }^{1} \mathrm{H}$ and ${ }^{13} \mathrm{C}$ chemical shifts are referenced to the signals of benzene- $d_{6}$, $\delta 7.16$ and $\delta$ 128.00, respectively. IR spectra were recorded on a JASCO FT/IR 5300 spectrophotometer, and UV on a Shimadzu UV-1600PC spectrometer. Optical rotations were measured on a JASCO P-2200 polarimeter. High resolution (HR)-FAB-MS (3-nitrobenzylalcohol as matrix) was obtained on a JEOL JMS-700 spectrometer. Silica gel $60 \mathrm{~N}$ (spherical neutral, 40-100 $\mu \mathrm{m}$, Kanto Chemical, Japan) was used for column chromatography. Medium-pressure liquid chromatography (MPLC) was performed on a Yamazen pump-540 apparatus using an ULTRA PACK glass column (silica gel, $40 \mu \mathrm{m}$, size B) (Yamazene, Japan). THF and $\mathrm{CH}_{2} \mathrm{Cl}_{2}$ were distilled from $\mathrm{LiAlH}_{4}$ and $\mathrm{P}_{2} \mathrm{O}_{5}$, respectively. (-)-Isopulegol was purchased from Tokyo Chemical Industry Co., Japan

Ee Determination of (+)-Neoisopulegol Neoisopulegol prepared from commercial (-)-isopulegol as described previously exhibited a positive sign of the optical rotation, $[\alpha]_{\mathrm{D}}^{25}+20.2\left(c=1.63, \mathrm{CHCl}_{3}\right)$; lit. $^{13)}-22.2$ for $(-)-(1 R, 3 S, 4 S)$ form)). ( $S$ )- and (R)- $\alpha$-Trifluoromethyl- $\alpha$-methoxyphenylacetic acid (MTPA) ester were prepared from neoisopulegol (1 mg) by reacting $(R)$ - and $(S)$-MTPA chlorides, respectively, in pyridine as described in our previous paper. ${ }^{16)}$ Pertinent ${ }^{1} \mathrm{H}$ NMR $\left(500 \mathrm{MHz}, \mathrm{CDCl}_{3}\right)$ data for the $(S)$-MTPA, $\delta: 5.56(\mathrm{~m}$, $0.17 \mathrm{H}, \mathrm{H}-3), 5.52$ (m, 0.83H, H-3), 4.85 (s, 0.83H, H-9a), 4.71 (s, 0.83H, H-9b), 4.68 (s, 0.17H, H-9a), 4.56 (s, 0.17H, H-9b), 1.77 (s, 2.49H, H-10), 1.71 (s, 0.51H, H-10), 0.90 (d, J=6.7 Hz, $0.51 \mathrm{H}, \mathrm{H}-7), 0.81(\mathrm{~d}, J=6.6 \mathrm{~Hz}, 2.49 \mathrm{H}, \mathrm{H}-7)$. The $(R)$-MTPA exhibited the complimentary ${ }^{1} \mathrm{H}-\mathrm{NMR}$ data.

(-)-Isopulegol separated by silica gel chromatography of the commercially available isopulegol was determined to be $66 \%$ ee by the Mosher's ester method. This finding supported the above ee value of $(+)$-neoisopulegol and implied that the optical rotation of enantimerically pure neoisopulegol is larger than the reported value.

$(1 S, 2 S, 5 R)-5-M e t h y l-2-[(S)-1-p$-toluensulfonyloxypropan2-yl]cyclohexan-1-ol Methoxymethyl Ether (6) A solution containing compound $\mathbf{5}(1.07 \mathrm{~g}, 4.95 \mathrm{mmol})$ and $\mathrm{TsCl}(2.00 \mathrm{~g}$, $10.5 \mathrm{mmol})$ in pyridine $(7.00 \mathrm{~mL})$ was stirred at room temperature for $2 \mathrm{~h}$. The mixture was stirred for $10 \mathrm{~min}$ after addition of a piece of ice. The usual work-up with EtOAc for extraction gave an oily product, which was chromatographed on silica gel with hexane-EtOAc $(10: 1)$ as an eluent to afford the tosylate $(1.67 \mathrm{~g}, 91 \%)$ as colorless needles, $\mathrm{mp} 65-66^{\circ} \mathrm{C}$ (from hexane). $[\alpha]_{\mathrm{D}}^{25}+17.3\left(c=2.20, \mathrm{CHCl}_{3}\right)$. IR $\left(\mathrm{CHCl}_{3}\right) \mathrm{cm}^{-1}: 2926$, 1597, 1455, 1359, 1175, 1150, 1097, 1038, 963, 938. ${ }^{1} \mathrm{H}-\mathrm{NMR}$ $\delta$ : $0.84\left(\mathrm{~d}, J=6.0 \mathrm{~Hz}, \mathrm{CH}_{3}-5\right), 0.97\left(\mathrm{~d}, J=6.8 \mathrm{~Hz}, \mathrm{CH}_{3}-2^{\prime}\right), 2.45$ (s, $\left.p-\mathrm{CH}_{3}\right), 3.32\left(\mathrm{~s}, \mathrm{OCH}_{3}\right), 3.82$ (m, H-1), 3.97 (dd, $J=9.2$, $\left.5.6 \mathrm{~Hz}, \mathrm{Ha}-1^{\prime}\right), 4.07$ (dd, $\left.J=9.2,3.2 \mathrm{~Hz}, \mathrm{Hb}-1^{\prime}\right), 4.52,4.66(1 \mathrm{H}$ each, d, $\left.J=6.8 \mathrm{~Hz}, \mathrm{OCH}_{2} \mathrm{O}\right), 7.34,7.78(2 \mathrm{H}$ each, d, $J=8.0 \mathrm{~Hz}$, aromatic). ${ }^{13} \mathrm{C}-\mathrm{NMR} \delta$ : 15.3, 21.7, 22.3, 23.9, 26.0, 34.1, 34.6, 38.7, 42.9, 55.7, 73.3, 74.0, 95.0, 127.8, 129.6, 133.0, 144.5. Anal. Calcd for $\mathrm{C}_{19} \mathrm{H}_{30} \mathrm{O}_{5} \mathrm{~S}$ : C, 61.59; H, 8.16; S, 8.65. Found: C, 61.42; H, 8.00; S, 8.74.

$(1 S, 2 S, 5 R)-5-M e t h y l-2-[(R)-6-m e t h y l h e p t-5-e n-2-y l] c y-$ clohexan-1-ol Methoxymethyl Ether (7) 3-Methyl-2-butenyl chloride $(1.73 \mathrm{~mL}, 17.8 \mathrm{mmol})$ was added dropwise to a stirring suspension of magnesium turnings $(340 \mathrm{mg}, 14.0 \mathrm{mmol})$ in dry
THF $(30 \mathrm{~mL})$ at $-20^{\circ} \mathrm{C}$ under $\mathrm{N}_{2}$ and the mixture was stirred at the same temperature for $1 \mathrm{~h}$. The resulting Grignard solution was warmed to $0^{\circ} \mathrm{C}$, and $\mathrm{CuI}(200 \mathrm{mg}, 1.05 \mathrm{mmol})$ and then a solution of the tosylate $6(1.67 \mathrm{~g}, 4.51 \mathrm{mmol})$ in dry THF $(1.0 \mathrm{~mL})$ were added. The mixture was stirred at $40^{\circ} \mathrm{C}$ for $2 \mathrm{~h}$ and cooled with an ice water bath. Ether and brine were added to the mixture and the ether layer was washed with aq. $\mathrm{NH}_{4} \mathrm{Cl}$, dried over $\mathrm{Na}_{2} \mathrm{SO}_{4}$, and concentrated to give an oily product. This product was chromatographed by MPLC with hexane-toluene $(1: 1)$ as an eluent to afford coupling product $7(690 \mathrm{mg}, 57 \%)$ as a colorless oil. $[\alpha]_{\mathrm{D}}^{25}+11.3(c=1.20$, $\left.\mathrm{CHCl}_{3}\right)$. IR $\left(\mathrm{CHCl}_{3}\right) \mathrm{cm}^{-1}:$ 2924, 1455, 1377, 1150, 1091, 1040, 913. ${ }^{1} \mathrm{H}-\mathrm{NMR} \delta$ : $0.86\left(\mathrm{~d}, J=6.8 \mathrm{~Hz}, \mathrm{CH}_{3}-5\right), 0.93(\mathrm{~d}, J=6.6 \mathrm{~Hz}$, $\left.\mathrm{CH}_{3}-2^{\prime}\right), 1.60\left(\mathrm{~s}, \mathrm{CH}_{3}-6^{\prime}\right), 1.67\left(\mathrm{~s}, \mathrm{H}_{3}-7^{\prime}\right), 3.37\left(\mathrm{~s}, \mathrm{OCH}_{3}\right), 3.92$ (m, H-1), 4.59, 4.72 (1H each, d, $J=6.8 \mathrm{~Hz}, \mathrm{OCH}_{2} \mathrm{O}$ ), 5.10 (brt, $\left.J=6.5 \mathrm{~Hz}, \mathrm{H}-5^{\prime}\right) .{ }^{13} \mathrm{C}-\mathrm{NMR} \delta$ : 17.0, 17.6, 22.4, 24.6, 25.1, 25.7, 26.4, 33.4, 34.2, 35.2, 39.3, 46.3, 55.6, 74.0, 95.4, 125.1, 130.9. HR-FAB-MS $m / z$ : $269.2486[\mathrm{M}+\mathrm{H}]^{+}$(Calcd for $\mathrm{C}_{17} \mathrm{H}_{33} \mathrm{O}_{2}$ : 269.2481). The NMR analysis revealed the material to be accompanied by approximately $10 \%(1 S, 2 S, 5 R)$-2-isopropyl5-methylcyclohexan-1-ol methoxymethyl ether that was produced by the reduction of the tosyloxy group and could not be separated by MPLC.

$(1 S, 2 S, 5 R)-5$-Methyl-2-[(R)-6-methylhept-5-en-2-yl]cyclohexan-1-ol (8) A solution of the coupling product 7 $(420 \mathrm{mg}, 1.56 \mathrm{mmol})$ in $\mathrm{THF}(5.0 \mathrm{~mL})$ and $4 \mathrm{M} \mathrm{HCl}(0.50 \mathrm{~mL})$ was heated under reflux for $3 \mathrm{~h}$ and was cooled to room temperature. The usual work-up with ether for extraction gave an oily product, which was chromatographed on silica gel with hexane-ether $(20: 1)$ as an eluent to afford alcohol 8 $(240 \mathrm{mg}, 68 \%)$. Further elution with the same solvent yielded $(1 S, 2 S, 5 R)$-2-isopropyl-5-methylcyclohexan-1-ol (20 mg) as a colorless oil. $[\alpha]_{\mathrm{D}}^{25}-2.9\left(c=1.90, \mathrm{CHCl}_{3}\right)$, IR $\left(\mathrm{CHCl}_{3}\right) \mathrm{cm}^{-1}$ : 3618, 2920, 1451, 1377. ${ }^{1} \mathrm{H}-\mathrm{NMR} \delta: 0.87\left(\mathrm{~d}, J=6.3 \mathrm{~Hz}, \mathrm{CH}_{3}-5\right)$, $0.96\left(\mathrm{~d}, J=6.6 \mathrm{~Hz}, \mathrm{CH}_{3}-2^{\prime}\right), 1.60\left(\mathrm{~s}, \mathrm{CH}_{3}-6^{\prime}\right), 1.67\left(\mathrm{~s}, \mathrm{H}_{3}-7^{\prime}\right)$, 4.10 (m, H-1), 5.10 (brt, $\left.J=7.2 \mathrm{~Hz}, \mathrm{H}-5^{\prime}\right) .{ }^{13} \mathrm{C}-\mathrm{NMR} \delta: 16.8$, 17.6, 22.3, 24.2, 25.1, 25.7, 26.0, 33.8, 34.4, 35.1, 42.7, 45.9, 67.8, 124.9, 131.1. Anal. Calcd for $\mathrm{C}_{15} \mathrm{H}_{28} \mathrm{O}: \mathrm{C}, 80.29 ; \mathrm{H}, 12.58$. Found: C, 80.01; H, 12.32 .

(2S,5R)-5-Methyl-2-[(R)-6-methylhept-5-en-2-yl]cyclohexan-1-one (9) Tetrapropylammonium perruthenate $(18 \mathrm{mg}$, $51.2 \mu \mathrm{mol})$, 4-methylmorpholine- $N$-oxide $(176 \mathrm{mg}, 1.50 \mathrm{mmol})$ and molecular sieves $4 \mathrm{~A}$ (powdered, $500 \mathrm{mg}$ ) were added to a stirred solution of alcohol $8(220 \mathrm{mg}, 980 \mu \mathrm{mol})$ in dry $\mathrm{CH}_{2} \mathrm{Cl}_{2}$ (3.0 mL) under $\mathrm{N}_{2}$, and the mixture was stirred at room temperature for $1 \mathrm{~h}$. The reaction mixture was diluted with ether $(15 \mathrm{~mL})$, subjected to a Florisil column and eluted with ether. Concentration of the filtrate yielded an oily product, which was chromatographed on silica gel with hexane-toluene $(2.5: 1)$ as an eluent to afford ketone $9(175 \mathrm{mg}, 80 \%)$ as a colorless oil. $[\alpha]_{\mathrm{D}}^{25}-17.5\left(c=1.90, \mathrm{CHCl}_{3}\right)$, IR $\left(\mathrm{CHCl}_{3}\right) \mathrm{cm}^{-1}$ : 2928, 1703, 1455, 1377. ${ }^{1} \mathrm{H}-\mathrm{NMR} \delta: 0.92\left(\mathrm{~d}, J=7.0 \mathrm{~Hz}, \mathrm{CH}_{3}-5\right)$, $1.00\left(\mathrm{~d}, J=6.5 \mathrm{~Hz}, \mathrm{CH}_{3}-2^{\prime}\right), 1.60\left(\mathrm{~s}, \mathrm{CH}_{3}-6^{\prime}\right), 1.68\left(\mathrm{~s}, \mathrm{H}_{3}-7^{\prime}\right)$, 5.12 (brt, $J=7.2 \mathrm{~Hz}, \mathrm{H}-5^{\prime}$ ). ${ }^{13} \mathrm{C}-\mathrm{NMR} \delta: 17.5,17.6,22.3,25.7$, 26.0, 28.1, 31.0, 33.2, 34.0, 35.2, 50.9, 55.3, 124.8, 131.2, 212.2. Anal. Calcd for $\mathrm{C}_{15} \mathrm{H}_{26} \mathrm{O}: \mathrm{C}, 81.02 ; \mathrm{H}, 11.79$. Found: C, 80.96; $\mathrm{H}, 11.50$.

$(2 S, 5 R, 6 S)-5$-Methyl-2-[(R)-6-methylhept-5-en-2-yl]-6(3-oxobutyl)cyclohexan-1-one (10) $n$-BuLi $(1.40 \mathrm{M}, 0.80 \mathrm{~mL}$, $1.12 \mathrm{mmol})$ was added to a solution of diisopropylamine $(158 \mu \mathrm{L}, 1.21 \mathrm{mmol})$ in dry THF $(3.0 \mathrm{~mL})$ at $-78^{\circ} \mathrm{C}$ under $\mathrm{N}_{2}$ 
and the mixture was stirred at the same temperature for $1 \mathrm{~h}$. A solution of ketone $9(75 \mathrm{mg}, 337 \mu \mathrm{mol})$ in dry THF $(0.50 \mathrm{~mL})$ was added to the resulting lithium diisopropylamide solution and the mixture was stirred at $-78^{\circ} \mathrm{C}$ for $1 \mathrm{~h}$. 3-Trimethylsilylbut-3-en-2-one (154 mg, $1.08 \mathrm{mmol})$ was added dropwise, and the mixture was warmed up from -78 to $0^{\circ} \mathrm{C}$ over a period of $1 \mathrm{~h}$. Next, $4 \mathrm{~N} \mathrm{HCl}(3.00 \mathrm{~mL})$ was added, and the mixture was stirred without cooling for $20 \mathrm{~min}$. The usual work-up with ether for extraction afforded an oily product, which was chromatographed on silica gel with hexane-toluene $(1: 1)$ as an eluent to recover the starting ketone $(17 \mathrm{mg})$. Further elution with hexane-ether $(10: 1)$ afforded diketone 10 (48 $\mathrm{mg}, 49 \%)$ as a colorless oil. $[\alpha]_{\mathrm{D}}^{25}-34.4\left(c=0.86, \mathrm{CHCl}_{3}\right)$, IR $\left(\mathrm{CHCl}_{3}\right)$ $\mathrm{cm}^{-1}:$ 2931, 1706, 1451, 1377. ${ }^{1} \mathrm{H}-\mathrm{NMR} \delta: 0.90(\mathrm{~d}, J=6.8 \mathrm{~Hz}$, $\left.\mathrm{CH}_{3}-5\right), 1.06\left(\mathrm{~d}, J=6.1 \mathrm{~Hz}, \mathrm{CH}_{3}-2^{\prime}\right), 1.61$ (s, $\left.\mathrm{CH}_{3}-6^{\prime}\right), 1.68$ (s, $\left.\mathrm{H}_{3}-7^{\prime}\right), 2.13$ (s, $\left.\mathrm{H}_{3}-4^{\prime \prime}\right), 5.12$ (brt, $\left.J=7.2 \mathrm{~Hz}, \mathrm{H}-5^{\prime}\right) .{ }^{13} \mathrm{C}-\mathrm{NMR} \delta$ : 17.7, 17.7, 20.3, 20.7, 25.7, 25.8, 29.5, 29.9, 31.2, 33.1, 34.9, 40.4, $41.4,56.4,57.0,124.8,131.2,209.2,213.3$. HR-FAB-MS $\mathrm{m} / \mathrm{z}$ : 293.2474 [M+H] $]^{+}$(Calcd for $\mathrm{C}_{19} \mathrm{H}_{33} \mathrm{O}_{2}:$ : 293.2481).

The Enone (11) A mixture of $10(45 \mathrm{mg}, 154 \mu \mathrm{mol})$ and $\mathrm{Ba}(\mathrm{OH})_{2} \cdot 8 \mathrm{H}_{2} \mathrm{O}(81 \mathrm{mg}, 257 \mu \mathrm{mol})$ in $\mathrm{EtOH}(0.40 \mathrm{~mL})$ was stirred at room temperature for $2 \mathrm{~h}$ under $\mathrm{N}_{2}$. The usual workup with ether for extraction gave an oily product, which was chromatographed on silica gel with hexane- $\mathrm{CHCl}_{3}(1: 1)$ as an eluent to afford enone $\mathbf{1 1}(16 \mathrm{mg}, 38 \%)$ as a colorless oil. $[\alpha]_{\mathrm{D}}^{25}-31.4\left(c=0.28, \mathrm{CHCl}_{3}\right) . \mathrm{UV} \lambda_{\max }(\mathrm{MeOH}) \mathrm{nm}(\log \varepsilon)$ : 241 (4.32). IR $\left(\mathrm{CHCl}_{3}\right) \mathrm{cm}^{-1}:$ 2927, 1662, 1614, 1454, 1379. ${ }^{1} \mathrm{H}-\mathrm{NMR}\left(500 \mathrm{MHz}, \mathrm{CDCl}_{3}\right) \delta: 0.98\left(\mathrm{~d}, J=6.7 \mathrm{~Hz}, \mathrm{H}_{3}-20\right), 1.03$ (d, $J=6.5 \mathrm{~Hz}, \mathrm{H}_{3}-18$ ), 1.62 (s, $\mathrm{H}_{3}-17$ ), 1.69 (s, $\mathrm{H}_{3}-16$ ), 5.12 (brt, $J=7.2 \mathrm{~Hz}, \mathrm{H}-14), 5.83$ (s, H-5). ${ }^{1} \mathrm{H}-\mathrm{NMR}(500 \mathrm{MHz}$, benzene$\left.d_{6}\right) \delta: 0.70\left(\mathrm{~d}, J=6.4 \mathrm{~Hz}, \mathrm{H}_{3}-20\right), 0.84(\mathrm{~m}, \mathrm{H}-2 \mathrm{ax}), 0.86(\mathrm{~d}$, $\left.J=6.8 \mathrm{~Hz}, \mathrm{H}_{3}-18\right), 0.90$ (m, H-3ax), 0.98 (m, H-12a), 1.00 (m, $\mathrm{H}-1), 1.27$ (m, H-8ax, H-9), 1.46 (m, H-2eq, H-12b), 1.62 (m, $\mathrm{H}-4), 1.62$ (s, H3-17), 1.67 (m, H-3eq), 1.73 (m, H-8eq), 1.75 (s, H3-16), 1.77 (m, H-11), 1.97 (m, H-13a), 2.06 (m, H-7ax, H13b), 2.25 (m, H-7eq), 5.25 (brt, $J=7.3 \mathrm{~Hz}, \mathrm{H}-14$ ), 6.03 (s, H-5). ${ }^{13} \mathrm{C}-\mathrm{NMR}\left(125 \mathrm{MHz}, \mathrm{CDCl}_{3}\right) \delta$ : 17.8, 18.4, 20.3, 25.6, 25.7, 25.9, 28.7, 31.7, 32.5, 35.1, 35.1, 39.1, 45.8, 50.6, 122.1, 124.4, 131.7, 169.6, 200.1. ${ }^{13} \mathrm{C}-\mathrm{NMR}\left(125 \mathrm{MHz}\right.$, benzene- $\left.d_{6}\right) \delta: 17.7$, $18.5,20.2,25.8,26.0,26.2,28.0,31.6,32.7,35.2,35.6,39.0$, $45.4,50.2,122.9,124.9,131.8,166.5,197.6$. HR-FAB-MS m/z: $275.2373[\mathrm{M}+\mathrm{H}]^{+}$(Calcd for $\left.\mathrm{C}_{19} \mathrm{H}_{31} \mathrm{O}, 275.2375\right)$.

Compound (2b) Tebbe reagent in toluene $(0.5 \mathrm{M}, 180 \mu \mathrm{L}$, $90.0 \mu \mathrm{mol})$ was added to a solution of enone $11(15 \mathrm{mg}$,
$55 \mu \mathrm{mol})$ in dry THF $(0.40 \mathrm{~mL})$ and the mixture was stirred at $0^{\circ} \mathrm{C}$ for $40 \mathrm{~min}$. The mixture was, diluted with hexane and applied to a silica gel column. Elution of the column with hexane furnished compound $\mathbf{2 b}(10.5 \mathrm{mg}, 70 \%)$. $[\alpha]_{\mathrm{D}}^{25}-72.2$ $\left(c=1.05, \mathrm{CHCl}_{3}\right)$. UV $\lambda_{\max }(\mathrm{MeOH}) \mathrm{nm}(\log \varepsilon): 240$ (3.92). IR $\left(\mathrm{CHCl}_{3}\right) \mathrm{cm}^{-1}:$ 2927, 1635, 1456, 1377, 885, 870. ${ }^{1} \mathrm{H}-\mathrm{NMR}$ $\left(500 \mathrm{MHz}, \mathrm{CDCl}_{3}\right) \delta: 0.94\left(\mathrm{~d}, J=6.3 \mathrm{~Hz}, \mathrm{H}_{3}-20\right), 0.98$ (d, $\left.J=6.8 \mathrm{~Hz}, \mathrm{H}_{3}-18\right), 1.64\left(\mathrm{~s}, \mathrm{H}_{3}-17\right), 1.71$ (s, H-16$), 4.66$ (s, H19a), 4.70 (s, H-19b), 5.19 (brt, $J=6.7 \mathrm{~Hz}, \mathrm{H}-14$ ), 5.90 (s, H-5). ${ }^{13} \mathrm{C}-\mathrm{NMR}\left(125 \mathrm{MHz}, \mathrm{CDCl}_{3}\right) \delta$ : 17.6, 18.7, 20.3, 25.8, 26.2, 27.5, 27.6, 28.9, 31.6, 32.3, 35.7, 39.3, 45.1, 49.3, 108.3, 120.8, 125.0, 131.4, 144.6, 147.0. ${ }^{1} \mathrm{H}-$ and ${ }^{13} \mathrm{C}-\mathrm{NMR}$ data recorded in benzene- $d_{6}$, see Table 1. HR-FAB-MS $m / z: 273.2598[\mathrm{M}+\mathrm{H}]^{+}$ (Calcd for $\mathrm{C}_{20} \mathrm{H}_{33}, 273.2582$ ). Compound $\mathbf{2 b}$ was unstable in $\mathrm{CDCl}_{3}$ based on the NMR results in which approximately half of $\mathbf{2} \mathbf{b}$ was decomposed after $24 \mathrm{~h}$.

\section{References}

1) Berrué F., McCulloch M. W. B., Kerr R. G., Bioorg. Med. Chem., 19, 6702-6719 (2011).

2) Look S. A., Fenical W., Matsumoto G. K., Clardy J., J. Org. Chem., 51, 5140-5145 (1986).

3) Duque C., Puyana M., Narváez G., Osorno O., Hara N., Fujimoto Y., Tetrahedron, 60, 10627-10635 (2004).

4) Duque C., Puyana M., Castellanos L., Arias A., Correa H., Osorno O., Asai T., Hara N., Fujimoto Y., Tetrahedron, 62, 4205-4213 (2006).

5) Potts B. C. M., Faulkner D. J., Jacobs R. S., J. Nat. Prod., 55, 1701-1717 (1992).

6) Kerr R. G., Kohl A. C., Ferns T. A., J. Ind. Microbiol. Biotechnol., 33, 532-538 (2006).

7) Coleman A. C., Kerr R. G., Tetrahedron, 56, 9569-9574 (2000).

8) Kohl A. C., Kerr R. G., Mar. Drugs, 1, 54-65 (2003).

9) Hui S. M., Ngo K. S., Brown G. D., J. Chem. Soc., Perkin Trans. 1, 1997, 3435-3442 (1997).

10) Ngo K. S., Brown G. D., Tetrahedron, 55, 15099-15108 (1999).

11) Ngo K. S., Brown G. D., J. Chem. Soc., Perkin Trans. 1, 2000, 189-194 (2000).

12) Casanovas J., Namba A. M., León S., Aquino G. L. B., da Silva G. V. J., Alemán C., J. Org. Chem., 66, 3775-3782 (2001).

13) Yadav J. S., Bhasker E. V., Srihari P., Tetrahedron, 66, 1997-2004 (2010).

14) Friedrich D., Bohlmann F., Tetrahedron, 44, 1369-1392 (1988).

15) Kitagawa I., Cui Z., Son B. W., Kobayashi M., Kyogoku Y., Chem. Pharm. Bull., 35, 124-135 (1987).

16) Asai T., Hara N., Fujimoto Y., Phytochemistry, 71, 877-894 (2010). 